\title{
Impact of agriculture crop residue burning on atmospheric aerosol loading - a study over Punjab State, India
}

\author{
Anu Rani Sharma ${ }^{1}$, Shailesh Kumar Kharol ${ }^{1}$, K. V. S. Badarinath ${ }^{1}$, and Darshan Singh ${ }^{2}$ \\ ${ }^{1}$ Atmospheric Science Section, National Remote Sensing Centre, Dept. of Space-Govt. of India, Balanagar, \\ Hyderabad 500 625, India \\ ${ }^{2}$ Physics Department, Punjabi University, Patiala 147 002, India
}

Received: 19 June 2009 - Revised: 6 January 2010 - Accepted: 26 January 2010 - Published: 2 February 2010

\begin{abstract}
The present study deals with the impact of agriculture crop residue burning on aerosol properties during October 2006 and 2007 over Punjab State, India using ground based measurements and multi-satellite data. Spectral aerosol optical depth (AOD) and Ångström exponent $(\alpha)$ values exhibited larger day to day variation during crop residue burning period. The monthly mean Ångström exponent " $\alpha$ " and turbidity parameter " $\beta$ " values during October 2007 were $1.31 \pm 0.31$ and $0.36 \pm 0.21$, respectively. The higher values of " $\alpha$ " and " $\beta$ " suggest turbid atmospheric conditions with increase in fine mode aerosols over the region during crop residue burning period. AURA-OMI derived Aerosol Index (AI) and Nitrogen dioxide $\left(\mathrm{NO}_{2}\right)$ showed higher values over the study region during October 2007 compared to October 2006 suggesting enhanced atmospheric pollution associated with agriculture crop residue burning.
\end{abstract}

Keywords. Atmospheric composition and structure (Aerosols and particles; Pollution - urban and regional)

\section{Introduction}

Biomass burning is one of the significant global source of atmospheric aerosols and trace gas emissions, which have a major impact on climate and human health (Vander werf et al., 2006; Kharol and Badarinath, 2006; Pandey et al., 2005). In urban areas, carbonaceous aerosols associated with vehicular combustion are major sources of pollution and radiative effect of carbonaceous aerosols constitutes one of the largest uncertainities in climate modeling (Andreae et al., 2005; Ramanathan et al., 2007). In addition to aerosol particles, biomass burning due to forest fires and crop residue burning are considered a major source of carbon dioxide

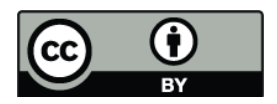

Correspondence to: K. V. S. Badarinath (badrinath_kvs@nrsc.gov.in)
$\left(\mathrm{CO}_{2}\right)$, carbon monoxide $(\mathrm{CO})$, methane $\left(\mathrm{CH}_{4}\right)$, volatile organic compounds (VOC), nitrogen oxides and halogen compounds (Guyon et al., 2005; Andreae and Merlet, 2001). The greenhouse gases $\mathrm{CO}_{2}$ and $\mathrm{CH}_{4}$ directly influence the global warming, while changes in oxidizing capacity to $\mathrm{CO}$ variability could perturb the growth rates of greenhouse gases. Recent study by Gustafsson et al. (2009) highlighted that biomass burning is one of the main causes for dense "brown clouds" in South Asia and 50-90\% of the South Asian BC originates from fossil fuel combustion (Stone et al., 2007; Menon et al., 2002). Smoke particles from biomass burning have direct radiative impact by scattering and absorbing shortwave radiation and indirect radiative impact by serving as cloud-condensation nuclei (CCN) and changing the cloud microphysical and optical properties (Cattani et al., 2005).

Agricultural crop residues are burnt during the months of October and November each year in the Indo-Gangetic Plains (IGP) which has significant impact on greenhouse gas emissions and aerosol loading (Badarinath et al., 2009). The IGP is a very important agro-ecoregion in South-Asia, which occupies nearly one-fifth of the total geographic area in four countries (Pakistan, India, Nepal and Bangladesh). The IGP in India covers $20 \%$ geographical area and contributes $\sim 42 \%$ to the total food grains production and holds nearly $\sim 40 \%$ of the total population (Tripathi et al., 2005). In the IGP region of India, $\sim 12$ million hectares is accounted for ricewheat crop rotation and harvesting of these crops with combine harvesters is very popular with the farmers of Punjab, Haryana and western Uttar Pradesh (Badarinath et al., 2009). These combine harvesting techniques in rice-wheat system leaves behind large quantities of straw in the field. The crop residues are subjected to open burning on account of high labor wages and anxiety of the farmers to get the crop produce collected and marketed at the earliest.

Punjab state straddles India's border with Pakistan and is often referred to as the country's "bread basket" because it produces two-thirds of the country's food grains. A

Published by Copernicus Publications on behalf of the European Geosciences Union. 
vast cloud of smoke engulfs the Punjab state, India, during October-November, as farmers burn the stubble of freshly harvested rice. The open burning results in perturbations to the regional atmospheric chemistry due to emissions of trace gases like $\mathrm{CO}_{2}, \mathrm{CO}, \mathrm{CH}_{4}, \mathrm{~N}_{2} \mathrm{O}, \mathrm{NO}_{\mathrm{x}}, \mathrm{NMHCs}$ and aerosols which is also a health hazard to local inhabitants (Wang and Christopher, 2003). The size of the crop area also makes stubble burning a serious problem as more than 17 million tones of rice stubble is burnt each year.

In the present study, we have examined the influence of rice crop stubble burning practices on the atmospheric aerosol properties using ground based measurements and satellite dataset during October 2006 and 2007 over the Patiala city, Punjab state, India. The area around Patiala city, Punjab State, India is predominantly rural, with farmers cultivating wheat, rice and other crops. Crop stubble burning in open fields in and around the city is a major pollution source during October-November each year (Mittal et al., 2009).

\section{Study area}

Patiala city, Punjab State, India is located at $\left(76^{\circ} 24^{\prime} \mathrm{E}\right.$, $30^{\circ} 19^{\prime} \mathrm{N}, 249 \mathrm{~m}$ a.s.l.), centre of the agrarian region of northwest India, close to Shivalik Hills in the east and Thar Desert in the southwest. The Punjab State suffers from severe fog, haze and smog during winter period due to anthropogenic activities and low temperatures (Mittal et al., 2009). The climate of the city is very hot in the summer and very cold in the winter. The region is generally dry and hot with maximum temperature of $43.1^{\circ} \mathrm{C}$ during May. The monsoon season lasts for three months with an annual rainfall of $688 \mathrm{~mm}$. January is the coldest month with mean monthly minimum temperature of $2.1^{\circ} \mathrm{C}$.

\section{Datasets and methodology}

\subsection{Multi Wavelength Radiometer (MWR)}

Multi-Wavelength Radiometer (MWR) designed and developed by the Space Physics Laboratory (SPL), Thiruvananthapuram operated for continuous and concurrent measurements of AOD at Patiala city of Punjab state, India. MWR takes measurements of the spectral extinction of ground reaching solar flux as a function of the solar zenith angle at ten wavelengths, centered at $380,400,450,500,600,650,750$, 850,935 and $1025 \mathrm{~nm}$ and having FWHM ranging from 6 to $10 \mathrm{~nm}$. The detailed description about the instrument has been published elsewhere (Moorthy et al., 1999; Gogoi et al., 2008).

The spectral dependence of the AOD was used to compute the Ångström's exponent “ $\alpha$ ”. A spectrally-averaged value of this exponent, which contains information about the size of the particles or the volume fraction of the fine versus coarse-mode particles (Schuster et al., 2006), can be obtained by fitting the Ångström's formula (Ångström, 1964):

$\mathrm{AOD}_{\lambda}=\beta \lambda^{-\alpha}$

where $\mathrm{AOD}_{\lambda}$ is estimated AOD at the wavelength $\lambda$, “ $\beta$ " is the Ångström's turbidity coefficient, which equals AOD at $\lambda=1 \mu \mathrm{m}$, and " $\alpha$ " is the Ångström exponent. The Ångström formula is a special case of a more complicated equation valid for a limited range of particle diameters and a limited interval of wavelengths. The validity of this theory presupposes that the Junge power law is valid for the particleradius range, where significant extinction takes place and that the spectral variation of the refractive index does not impose significant variations on the Mie extinction factor (Kaskaoutis et al., 2006). Taking the logarithms of both sides of Eq. (1) obtains:

$\ln \mathrm{AOD}_{\lambda}=-\alpha \ln \lambda+\ln \beta$

The Ångström exponent itself varies with wavelength. A more precise empirical relationship between aerosol extinction and wavelength is obtained with a second-order polynomial approximation (Pedros et al., 2003; Kaskaoutis and Kambezidis, 2006):

$\ln \mathrm{AOD}_{\lambda}=a_{2}(\ln \lambda)^{2}+a_{1} \ln \lambda+a_{o}$

where the coefficient " $a_{2}$ " accounts for a curvature often observed in sun photometry measurements. This curvature can be an indicator of the aerosol-particle size, with negative curvature indicating aerosol-size distributions dominated by fine-mode and positive curvature indicating size distributions with significant contribution by the coarse-mode aerosols (Schuster et al., 2006). In this study, " $\alpha$ " was computed in the wavelength interval $380-850 \mathrm{~nm}$, using the Eq. (2). The linear fit to the logarithmic function of Eq. (2) is the most precise method, although the results may also depend on the spectral interval considered (Pedros et al., 2003; Kaskaoutis and Kambezidis, 2008). The second-order polynomial fit (Eq. 3) was also applied to the AOD values at five wavelengths $(380,450,500,650$ and $850 \mathrm{~nm})$. Although the polynomial fit to Eq. (3) is more precise than the linear fit to Eq. (2), large errors can appear especially under low turbidity conditions. To limit these errors only the cases where the second-order polynomial fit was associated with $R^{2}>0.95$ were considered.

\subsection{MODIS Aerosol Optical Depth (AOD)}

Moderate Resolution Imaging Spectroradiometer (MODIS) acquires daily global data in 36 spectral bands from visible to thermal infrared (29 spectral bands with $1-\mathrm{km}, 5$ spectral bands with $500-\mathrm{m}$, and 2 spectral bands with $250-\mathrm{m}$, nadir pixel dimensions). The MODIS sensor is onboard the polar orbiting NASA-EOS Terra and Aqua spacecrafts with equator crossing times of 10:30 and 13:30 Local Solar Time 
(LST), respectively (Levy et al., 2007). Aerosol retrievals from MODIS data are performed over land and ocean surfaces by means of two separate algorithms described in literature (Kaufman and Tanre, 1998). The aerosol properties are derived by the inversion of the MODIS-observed reflectance using pre-computed radiative transfer look-up tables based on aerosol models (Remer et al., 2005; Levy et al., 2007). The initial versions of the MODIS algorithms have been under continued development, and have recently received an improved aerosol determination, via processing to Collection 5 (C005) (Levy et al., 2007). The data used in this study include Terra MODIS aerosol products, calculated using separate algorithms over land and ocean to obtain AOD at $550 \mathrm{~nm}\left(\mathrm{AOD}_{550}\right)$ and the proportion of $\mathrm{AOD}_{550}$ contributed to the fine-mode aerosols (determined as fine-mode fraction, FM); such estimations are only made over cloud-free regions (Remer et al., 2005). The C005 Level 3 (spatial resolution $1^{\circ} \times 1^{\circ}$ ) MODIS products were obtained from LADSWEB website (http://ladsweb.nascom.nasa.gov/).

\subsection{OMI Aerosol Index}

Aerosol Index (AI) values from the Ozone Monitoring Instrument (OMI) onboard the Finnish-Dutch AURA satellite are used. The AI, as defined in Eq. (4) below, is the residual between the measured radiance and the calculated one using the Lambert Equivalent Reflectivity (LER) assumption. Assuming a Rayleigh scattering atmosphere above a Lambertian surface, the Lambert Equivalent Reflectivity is defined as the value of the Lambertian spectral albedo for which the modeled and measured top of atmosphere (TOA) reflectance are equal. The LER in the multi-wavelength algorithm was determined using the radiative transfer code Doubling-Adding KNMI (DAK) (Curier et al., 2008).

$\mathrm{AI}=-100 \log \left\{\left[\frac{I \lambda_{1}}{I \lambda_{2}}\right]_{\text {meas }}\right\}+100 \log \left\{\left[\frac{I \lambda_{1}\left(A_{\mathrm{LER} \lambda_{1}}\right)}{I \lambda_{2}\left(A_{\mathrm{LER} \lambda_{2}}\right)}\right]_{\text {calc }}\right\}$

$A_{\text {LER }}$ is the wavelength-dependent surface Lambert Equivalent albedo. The UV aerosol index at $388 \mathrm{~nm}$ is calculated using the following wavelengths $\lambda_{1}=342.5 \mathrm{~nm}$ and $\lambda_{2}=388 \mathrm{~nm}$. Aerosol index (AI) is sensitive to elevated absorbing layers such as dust and biomass burning aerosols (de Graaf et al., 2005).

\subsection{OMI tropospheric $\mathrm{NO}_{2}$}

OMI/AURA $\mathrm{NO}_{2}$ total and tropospheric column L2 (V00) global product from GES-DISC (http://gdata1.sci.gsfc.nasa. gov/daac-bin/G3/gui.cgi?instance_id=omil2g) at $0.25 \mathrm{deg}$ spatial resolution were used in the study. The Atmospheric $\mathrm{NO}_{2}$ column densities use the Differential Optical Absorption Spectroscopy (DOAS) technique (Platt, 1994) and are retrieved using spectral measurements of the solar irradiance and earth shine radiance in the wavelength region 415$465 \mathrm{~nm}$ using the instrument's VIS detector at a spectral reso- lution of $0.5 \mathrm{~nm}$ (Celarier et al., 2008). Detailed descriptions of the algorithm for the standard $\mathrm{OMI} \mathrm{NO}_{2}$ data product are given in Boersma et al., 2002; Bucsela et al., 2006; Celarier et al., 2008.

\subsection{CALIPSO}

The Cloud-Aerosol Lidar and Infrared Pathfinder Satellite Observation (CALIPSO) provide new insight into the role of clouds and atmospheric aerosols (airborne particles) in regulating Earth's climate and air quality. CloudSat is a part of the A-train series satellite constellation that includes Aqua, Aura, and PARASOL satellites. CALIPSO has a $98^{\circ}$ inclination orbit and flies at an altitude of $705 \mathrm{~km}$ providing daily global maps of the vertical distribution of aerosols and clouds. CALIPSO was launched on 28 April 2006. The CALIPSO payload consists of three instruments: the CloudAerosol Lidar with Orthogonal Polarization (CALIOP), an Imaging Infrared Radiometer (IIR), and a moderate spatial resolution Wide Field-of-view Camera (WFC). CALIOP provides profiles of backscatter at 532 and $1064 \mathrm{~nm}$, as well as two orthogonal (parallel and perpendicular) polarization components at $532 \mathrm{~nm}$. A detailed discussion of CALIOP data products has been described elsewhere (Powell et al., 2009).

\subsection{MOPITT CO}

CO data from Measurements of Pollution in the Troposphere instrument (MOPITT) were analysed to assess the CO variations coinciding with crop residue burning period. MOPITT is a thermal nadir-viewing gas-correlation radiometer, which provides view of $\mathrm{CO}$ emissions with a horizontal resolution of $22 \mathrm{~km}$ (Liu et al., 2005). MOPITT retrievals provide average $\mathrm{CO}$ values separately resolved in two relatively broad layers of the atmosphere; in the lower troposphere from about $700-500 \mathrm{hPa}$, and in the upper troposphere from about 300-200 hPa (Deeter et al., 2004). Details on measurement and retrieval techniques from MOPITT have been described elsewhere (Deeter et al., 2004). We use version 3 of level 2 total column CO data available at the NASA (http://eosweb. larc.nasa.gov/PRODOCS/mopitt/table_mopitt.html) Langley Distributed Active Archive Center. The version 3 of level 2 total column CO data files contains the total column abundance and the profiles of $\mathrm{CO}$ at 7 heights.

\subsection{MODIS active fire locations}

Fire observations are performed four times a day from the Terra (10:30 and 22:30) and Aqua (13:30 and 01:30) platforms. MODIS Fire detection is performed using a contextual algorithm (Giglio et al., 2003) that exploits the strong emission of mid-infrared radiation from fires. The algorithm uses brightness temperatures derived from the MODIS 4 and $11 \mu \mathrm{m}$ channels. The description of MODIS fire products retrieval has been provided elsewhere (Giglio et 

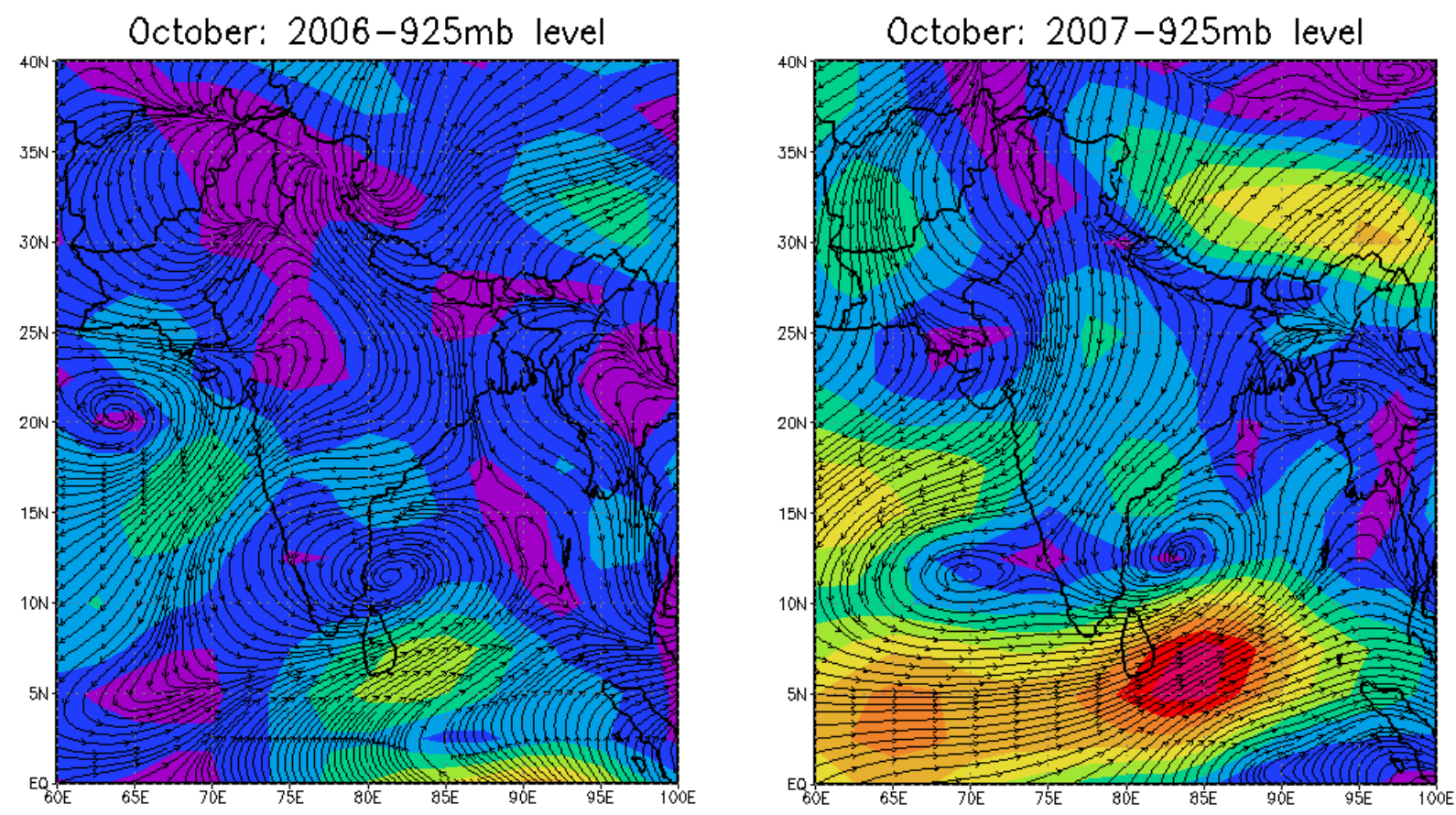

$\mathrm{m} / \mathrm{sec}$

Fig. 1. Synoptic wind patterns at $925 \mathrm{hPa}$ level over Indian region for the period of October 2006 and 2007.

al., 2003). We used MODIS active fire location composited for the period of October 2006 and 2007 from Russia web fire maps (http://maps.geog.umd.edu/activefire html/). The mean composite wind vector at 925-hpa level over the Indian region was obtained from NCEP/NCAR reanalysis website (http://www.cdc.noaa.gov/cgi-bin/data/composites/ printpage.pl). Air mass back trajectories ending at the Patiala city at three altitudes $(500 \mathrm{~m}, 1500 \mathrm{~m}$ and $3000 \mathrm{~m}$ a.s.l.) were calculated using the NOAA-HYSPLIT (National Oceanic and Atmospheric Administration Hybrid Single- Particle Lagrangian Integrated Trajectory) model (version 4) which includes vertical wind. This model was developed at the Air Resources Laboratory, National Oceanic and Atmospheric Administration, USA (Draxler and Rolph, 2003).

\section{Results and discussion}

\subsection{Meteorological conditions}

The wind vectors at $925 \mathrm{hPa}$ from NCEP were analysed to characterize the dispersion of aerosols in the study region during the study period. Figure 1 shows the average wind speed and direction at $925 \mathrm{hPa}$ over Indian region during October 2006 and 2007. A persistent north-westerly flow for October 2006 and northerly flow for October 2007 with high intensities in the northern part of India (Ganges valley) can be seen from the Fig. 1. The wind field confirms continental aerosols outflow over Arabian Sea (AS) during the study period. Recent studies by Badarinath et al. (2009a, b) reported the long range transport of aerosols/trace gases from agriculture crop residue burning regions to urban region of Hyderabad and Arabian Sea (AS). Earlier studies carried out by Deshpande and Kamra (2002) suggested long range transport of aerosols from the northern Indian subcontinent and South Asian region to the pristine oceanic atmosphere of the Southern Hemisphere by northeasterly winds of the Asian winter monsoon. Figure 2 shows the NOAAHYSPLIT derived five-day back trajectories ending at $\mathrm{Pa}-$ tiala at three altitudes $(500,1500$ and $3000 \mathrm{~m})$ on each day at 00:00 UTC during October 2006 and 2007. The north/north westerly winds were prominent over the region during the study period at three altitudes attributed to the biomass burning aerosols transport over the region. The variations in daily average temperature, relative humidity $(\mathrm{RH})$ and wind speed during October 2006 and October 2007 over Patiala city is shown in Fig. 3a-b. Air temperature was varying between $21.6^{\circ} \mathrm{C}-30.4{ }^{\circ} \mathrm{C}$ and $23.3^{\circ} \mathrm{C}-28.2^{\circ} \mathrm{C}$ during October 2006 and 2007, respectively (Fig. 3a). Relative humidity was ranging between $54.4 \%-70.6 \%$ and $45.8 \%-73.6 \%$ during October 2006 and 2007 (Fig. 3b).

\subsection{Aerosol properties over Patiala}

Aerosol optical depth (AOD) measurements were carried out using Multi Wavelength Radiometer (MWR) (Moorthy et al., 1999; Gogoi et al., 2008; Pillai and Murthy, 2004; Vinoj et al., 2004). Figure $4 \mathrm{a}-\mathrm{c}$ shows the comparative day-today variability of $\mathrm{AOD}_{500}$, Ångström Exponent " $\alpha$ " and turbidity parameter " $\beta$ " during October for the years of 2006 

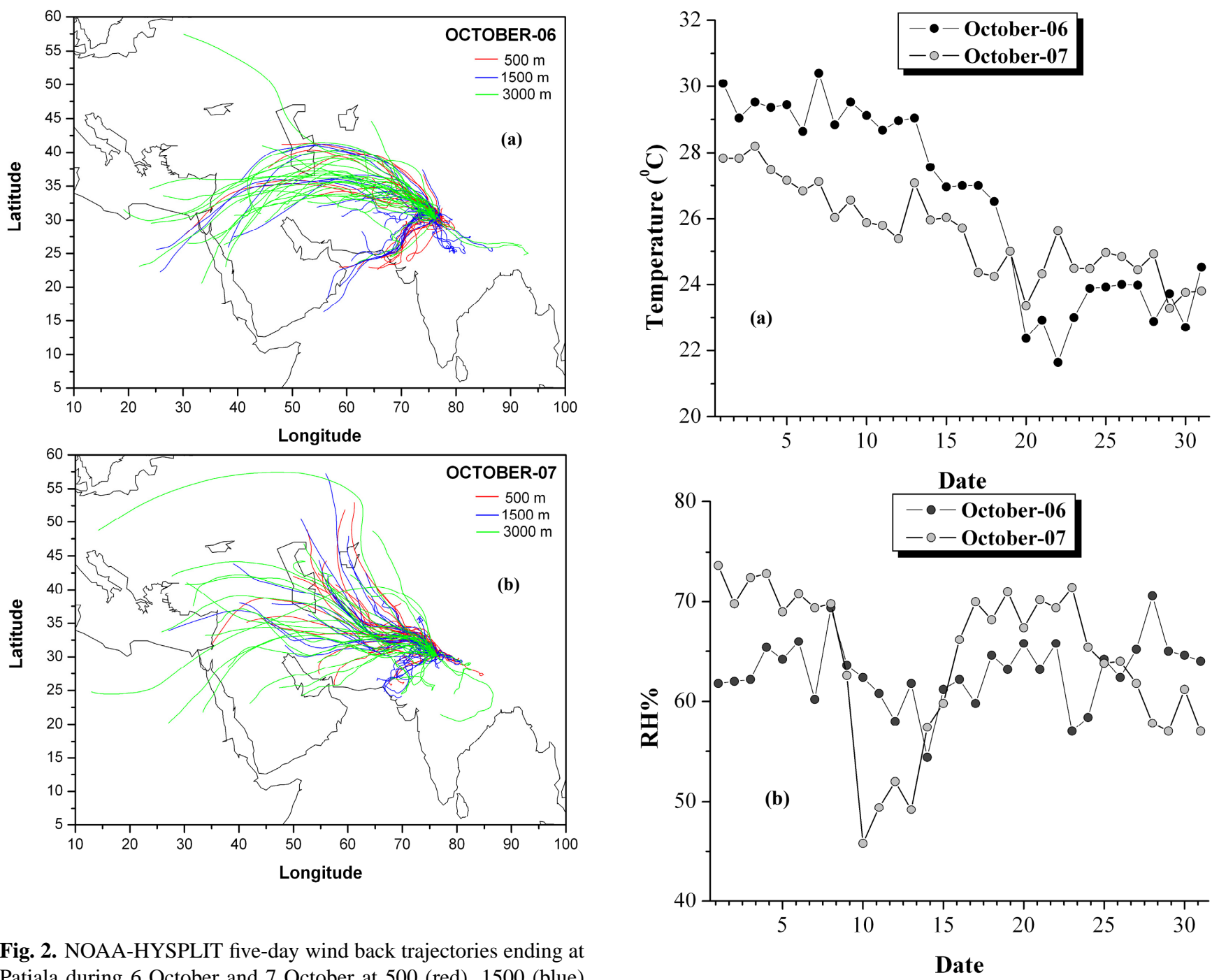

Fig. 2. NOAA-HYSPLIT five-day wind back trajectories ending at Patiala during 6 October and 7 October at 500 (red), 1500 (blue) and $4000 \mathrm{~m}$ (green).

and 2007. Day-to-day increase in $\mathrm{AOD}_{500}$ values was observed during October 2006 and 2007 suggesting additional loading of aerosols over the region associated with agriculture crop residue burning practices (Fig. 13). The monthly mean $\mathrm{AOD}_{500}$ exhibited larger values during October 2007 $(\sim 0.97 \pm 0.56)$ compared to October $2006(0.76 \pm 0.45)$ suggesting a $\sim 21 \%$ increase in aerosols loading over the region. The Ångström exponents were derived from the AOD values using the least-squares method covering the spectral range 380-850 $\mathrm{nm}$ (Das et al., 2008). The abundance of accumulation $(0.1 \mu \mathrm{m}<$ radius $<1.0 \mu \mathrm{m})$ mode particles as reflected in high values of the Ångström exponent " $\alpha$ " with a simultaneous increase in the turbidity parameter " $\beta$ " can be noticed during October 2007 compared to October 2006 (Fig. $4 \mathrm{~b}, \mathrm{c}$ ). The monthly mean " $\alpha$ " values during October $2007(1.31 \pm 0.31)$ were observed to be high compared to October $2006(1.10 \pm 0.26)$. Similarly, monthly mean " $\beta$ " values also showed higher values $(0.36 \pm 0.21)$ during Octo-

Fig. 3. Day-to-day variation of (a) average temperature and (b) Relative humidity (RH) during October 2006 and 2007.

ber 2007 compared to October $2006(0.32 \pm 0.15)$ suggesting more turbid atmospheric conditions and increase in accumulation mode aerosols particles over the region during October 2007 (Badarinath et al., 2009). The Ångström parameter $(\alpha)$ and turbidity coefficient $(\beta)$ showed $18 \%$ and $10 \%$ increase respectively during October 2007 and were attributed to agriculture crop residue burning activities over the region.

Figure 5a-b shows the scatter plot of the coefficient $a_{2}$ (curvature in the polynomial fit) against $\mathrm{AOD}_{500}$ during October 2006 and 2007. The correlation between " $a_{2}$ " and $\mathrm{AOD}_{500}$ provides information on the atmospheric condition under which " $\alpha$ " is independent from wavelength. The data lying on or near the $a_{2}=0$ line corresponds to bimodal lognormal aerosol size distribution without curvature, negative $a_{2}$ values corresponds to fine mode aerosols and positive $a_{2}$ 

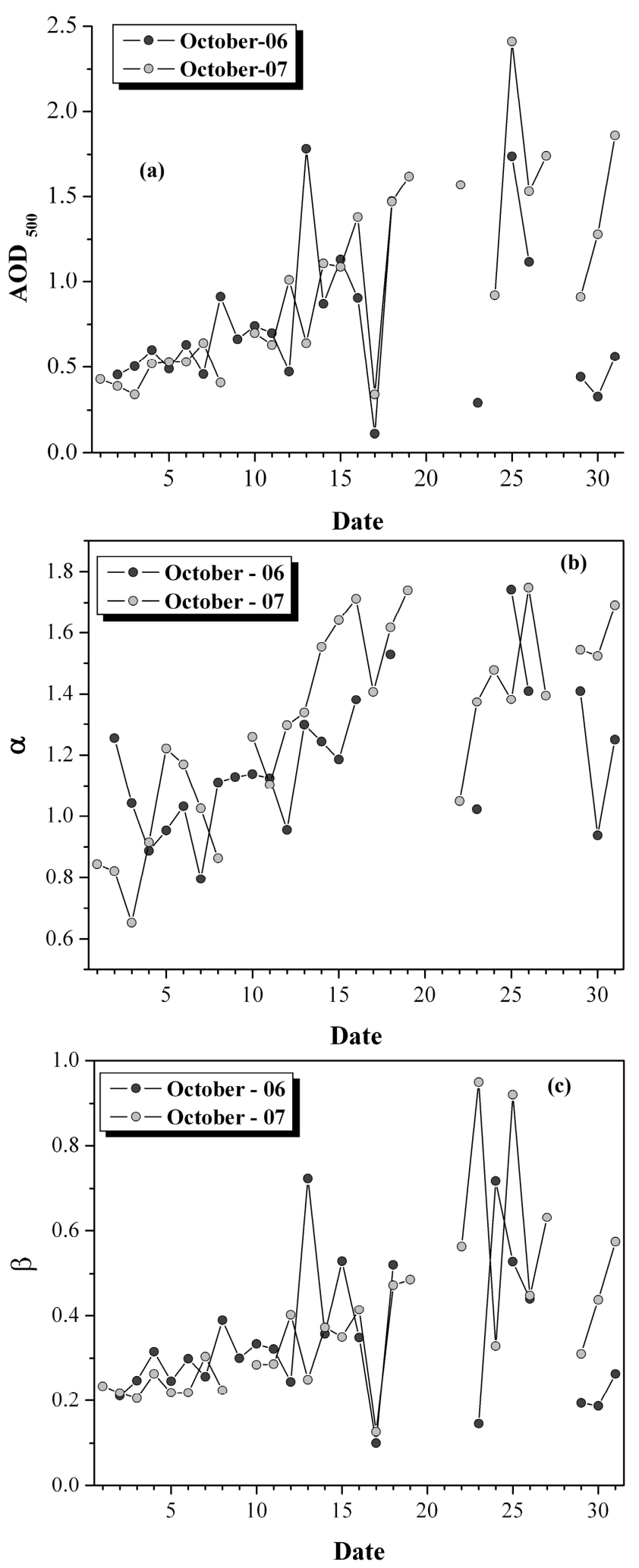

Fig. 4. Day-to-day variation of (a) MWR measured $\mathrm{AOD}_{500}$, (b) Ångström Exponent $(\alpha)$ and (c) Turbidity parameter $(\beta)$ during October 2006 and 2007.
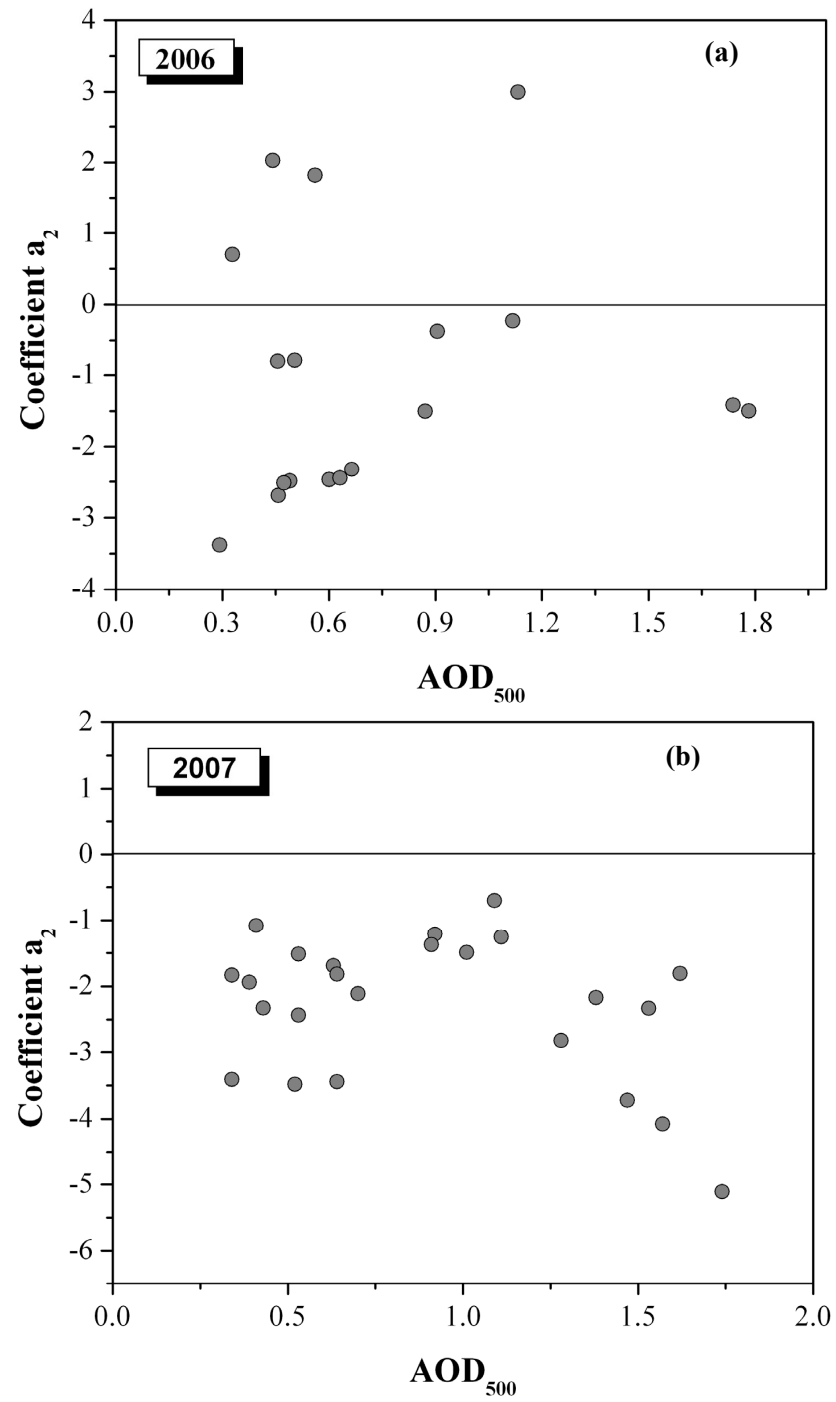

Fig. 5. Scatter plot of coefficient $a_{2}$ against $\mathrm{AOD}_{500}$ during (a) October 2006 and (b) October 2007.

values mainly indicates presence of coarse mode aerosol particles (Kaskaoutis et al., 2007; Schuster et al., 2006). During October 2007 " $a_{2}$ " exhibits negative values suggesting abundance of accumulation mode aerosol particles over the region (Fig. 5a-b). However, during October 2006, majority of $a_{2}$ values were negative, but few positive values and near zero values occurred, suggesting presence of coarse mode aerosol particles along with accumulation mode aerosol particles over the region.

\subsection{Satellite observations on emission from agriculture crop residue burning}

MODIS images have been extensively used for monitoring of forest fires, dust outbreaks, severe storms, cyclones, volcanoes etc over the globe (Kaskaoutis et al., 2008; Badarinath 

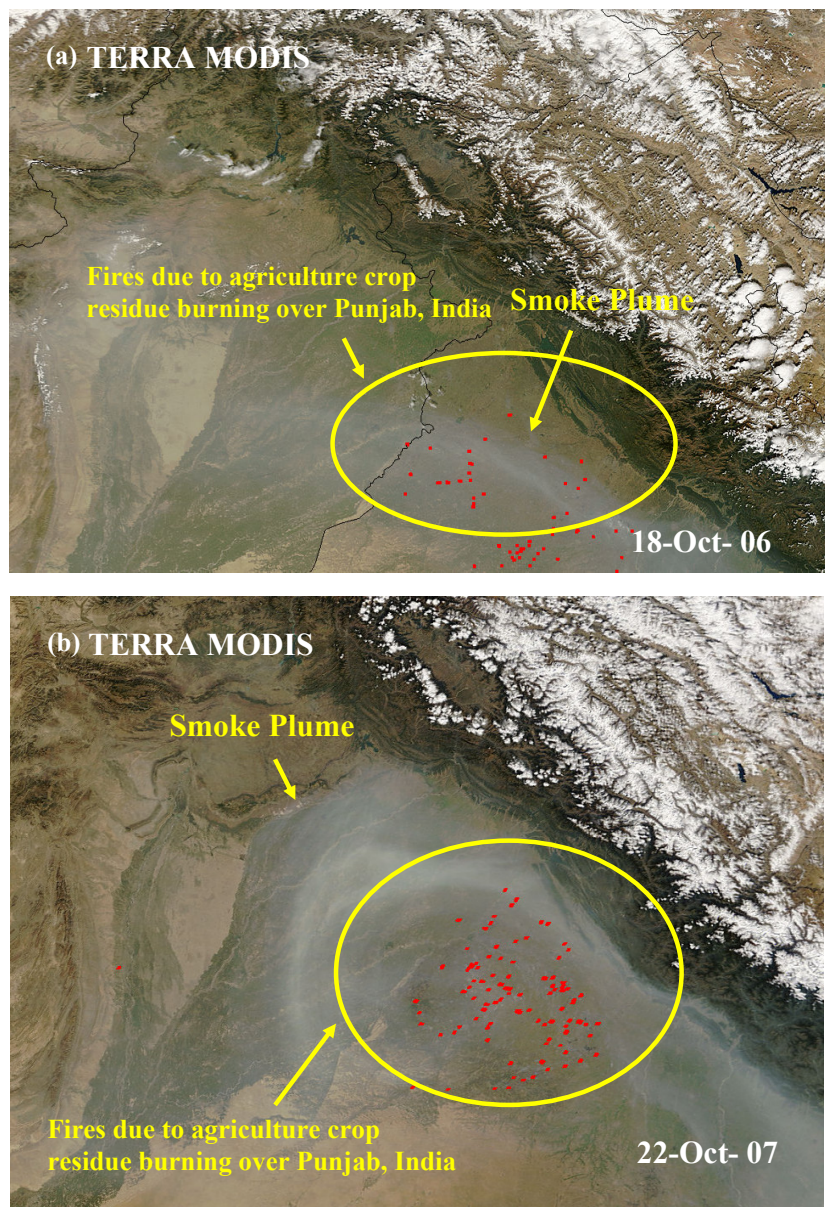

Fig. 6. Terra MODIS true color composite of study area showing smoke due to crop residue burning and fires in red color on 18 October 2006 and 22 October 2007.

et al., 2008, 2009c; Rothery, et al., 2005). Figure 6a-b shows the Terra MODIS true color composite images on 18 October 2006 and 22 October 2007 over Punjab state, India. At the base of the Himalaya mountain in northwestern India, a large and intense smoke plume extending over the Indo Gangetic Plains (IGP) and Punjab with active fires marked with red dots can be clearly seen in Fig. 6a-b associated with agriculture crop residue burning (Badarinath et al., 2006; Mittal et al., 2009). Figure 7 shows the daily variation of Terra MODIS AOD 550 during October 2006 and 2007. The day-today variation of Terra MODIS $\mathrm{AOD}_{550}$ also shows the higher values similar to MWR AOD 500 (Fig. 4a) variations over the region during October 2006 and 2007 . The linear regression analysis between ground based MWR measurements on $\mathrm{AOD}_{500}$ and Terra MODIS AOD 550 during October 2007 exhibited good correlation of $\sim 0.86$ (Fig. 8).

In addition, AURA-OMI Aerosol Index (AI) was also analysed over the region during the study period. Aerosol Index (AI) is sensitive to a range of UV-absorbing aerosols

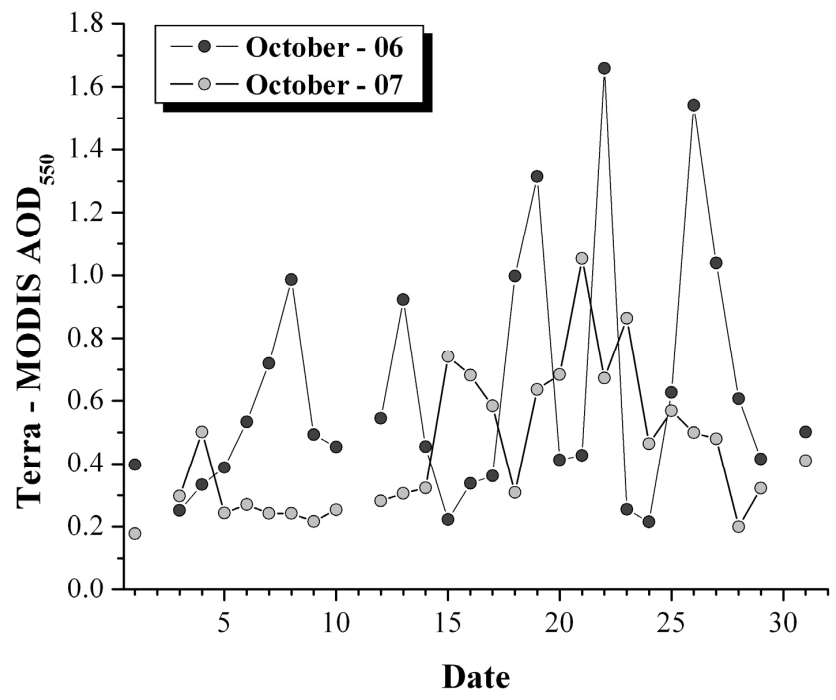

Fig. 7. Day-to-day variation of Terra MODIS AOD 500 during October 2006 and 2007.

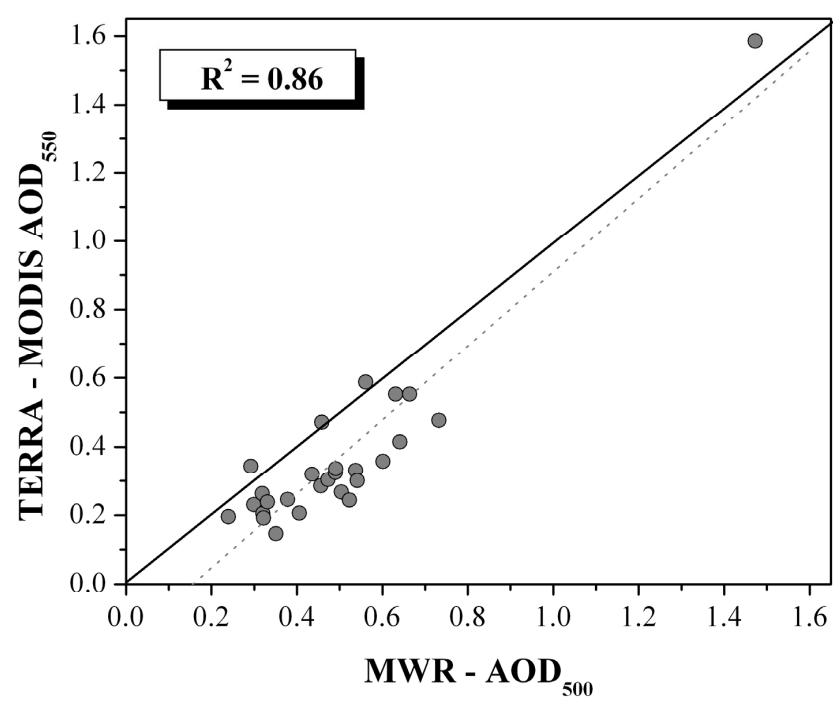

Fig. 8. Scatter plot of MODIS $\mathrm{AOD}_{550}$ vs. MWR measured $\mathrm{AOD}_{500}$ over Patiala city, Punjab state, India.

such as mineral dust, volcanic ash, and black carbon from fossil-fuel combustion sources and biomass burning (Badarinath et al., 2007). The UV surface reflectivity is typically low and nearly constant over both land and sea, which allows OMI to detect aerosols over both land and ocean. Extensive analysis of the seasonal and interannual variability of TOMS-AI values has been carried out over India by Habib et al. (2006). The spatial distribution of OMI derived monthly mean Aerosol Index during October 2006 and 2007 are shown in the Fig. 9a-b. The typical AI values during October 2006 over the region were in the range of $\sim 1-1.4$, while for October 2007 , it varied between $\sim 1$ to $\sim 2$. The high OMI AI suggested increased concentration 

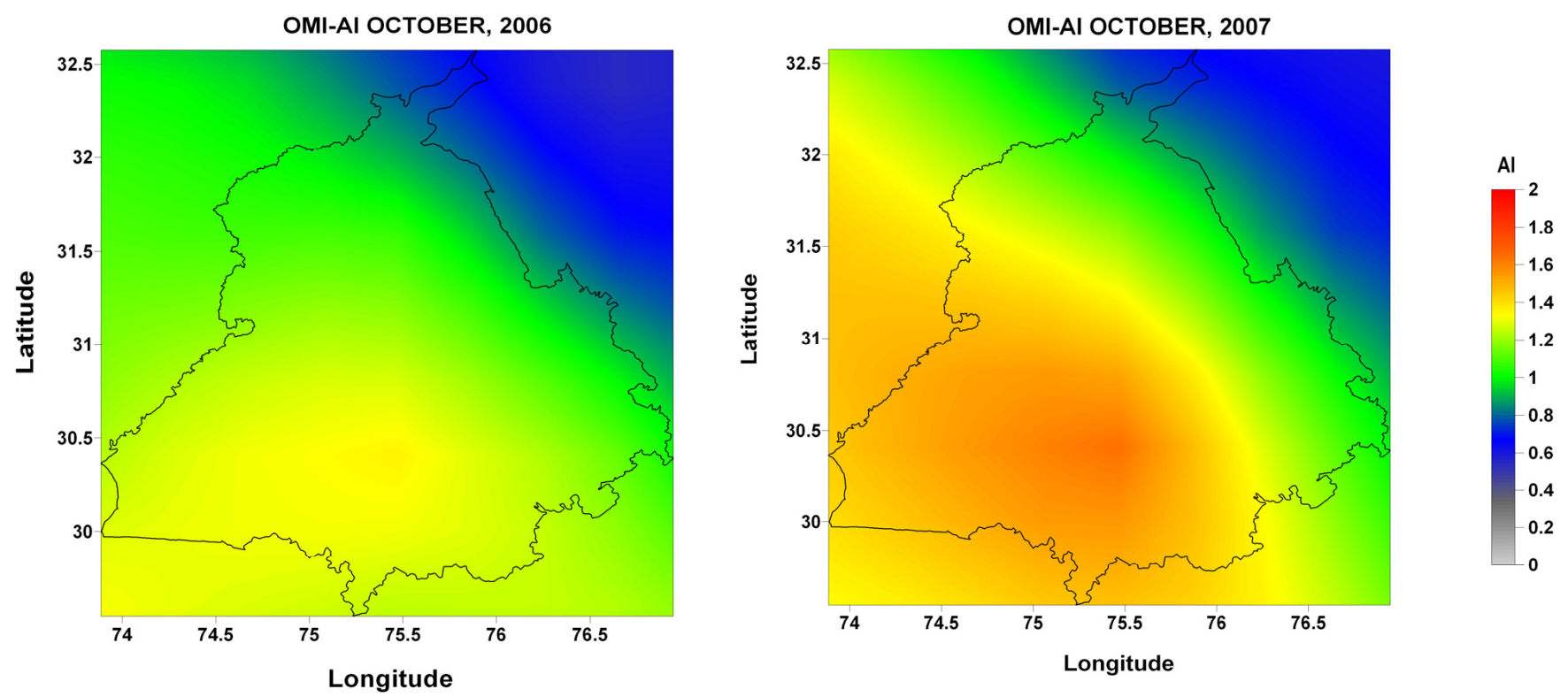

Fig. 9. Spatial variation of OMI-AI over Punjab state during October 2006 and 2007.

$10^{15} \mathrm{molec} / \mathrm{cm} 2$
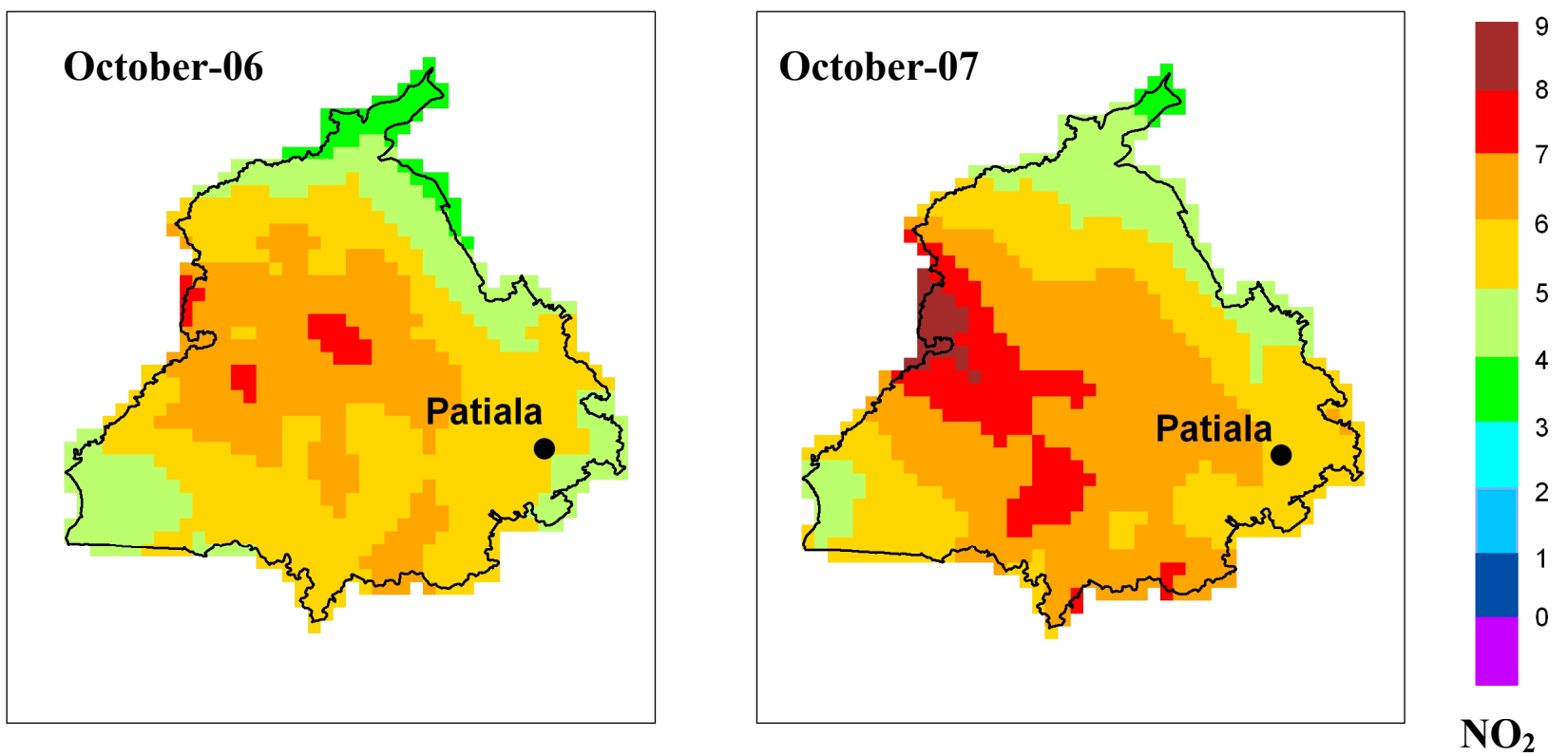

Fig. 10. Spatial variation of OMI-NO $\mathrm{NO}_{2}$ over Punjab state, India during October 2006 and 2007.

of absorbing aerosols in the atmosphere from crop residue burning over the study region. Figure 10a-b shows the OMI derived monthly mean tropospheric columnar $\mathrm{NO}_{2}$ during October 2006 and 2007 over Punjab state with Patiala city location marked on the figure. Figure 10 suggests relatively higher values of $\mathrm{NO}_{2}$ in the range of minimum $\sim 4$ to a maximum of $\sim 9\left(10^{15} \mathrm{molec} \mathrm{cm}^{-2}\right)$ during October 2007, compared to October 2006. The higher $\mathrm{NO}_{2}$ concentration in
October 2007 compared to October 2006 may be related with the intensity of the fires due to agriculture crop residue burning and the larger AOD, $\alpha$ and $\beta$ values.

Satellite remote sensing provides an opportunity of making global measurements of tropospheric trace gases and aerosols over extended periods of time (Edwards et al., 2004; Andreae and Merlet, 2001). Figure 11a-b shows the monthly mean distribution of daytime total columnar $\mathrm{CO}$ abundance 

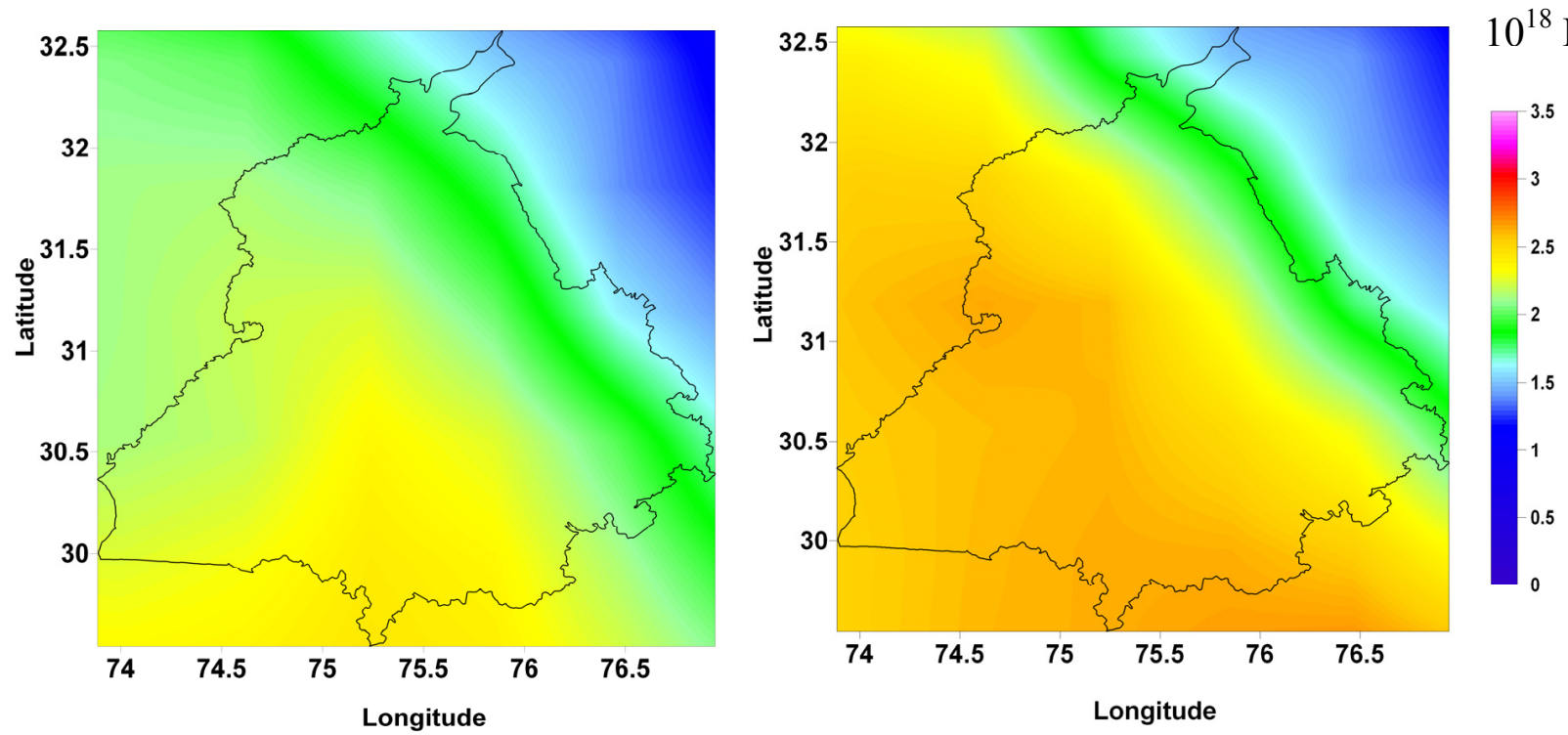

Fig. 11. Spatial variation of MOPITT CO over Punjab state during October 2006 and 2007.

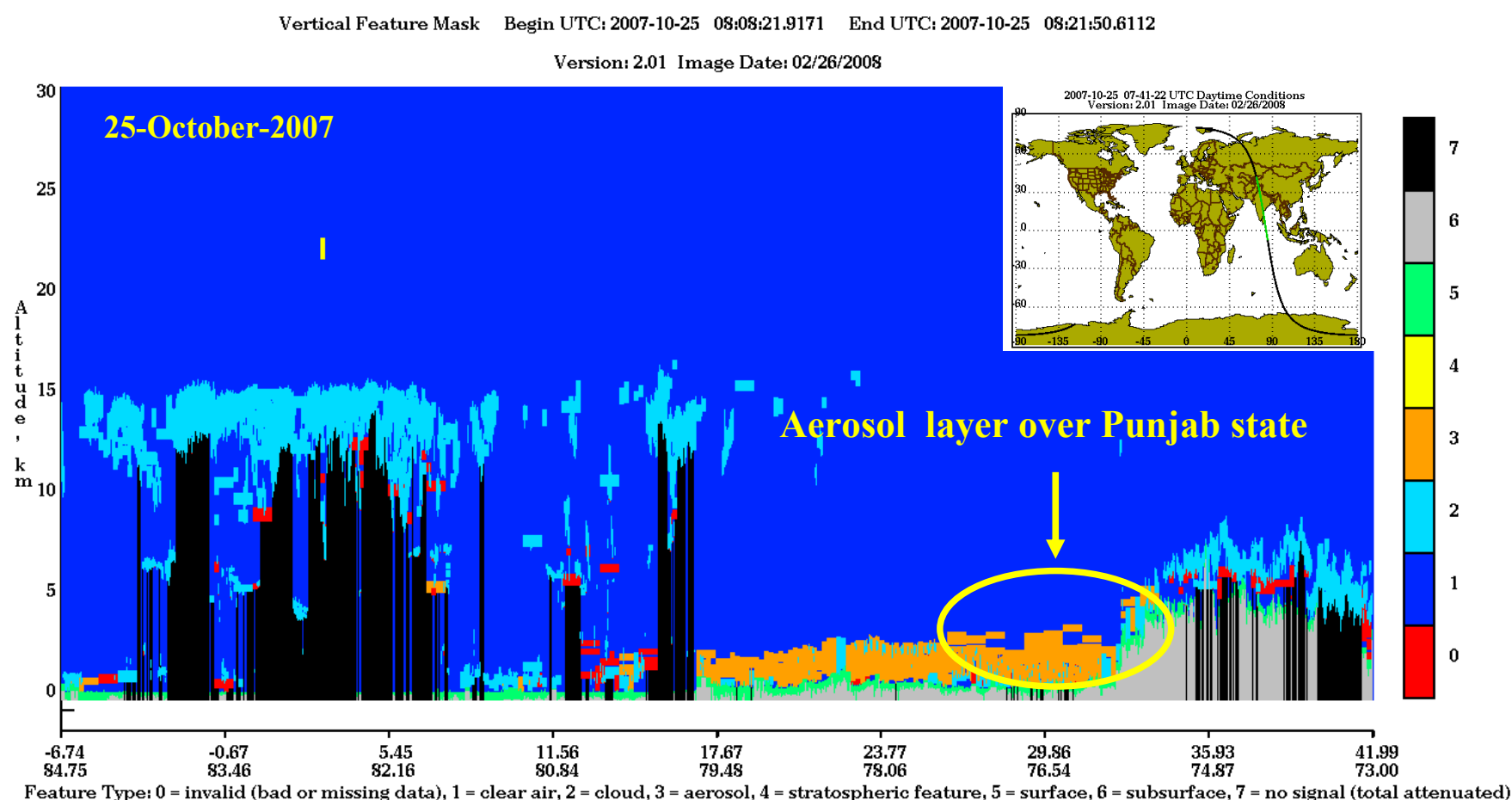

Fig. 12. Calipso derived vertical feature mask image showing high aerosol loading over central region of India on 25 October 2007.

at $850 \mathrm{hPa}$ measured by MOPITT during October 2006 and 2007 over Punjab state, India. MOPITT observed high levels of carbon monoxide (red and golden yellow pixels) over the study region during October 2007 associated with agriculture crop residue burning. Figure 12 shows the CALIPSOderived vertical feature mask image covering the central part of India on 25 October 2007. In the lower part of Fig. 12 the coordinates of the overpass (latitude above and longitude below) are also given. The daytime pass of CALIPSO was at 08:08 to 08:21 UTC mainly covering parts of the Punjab, Haryana, Rajasthan, Madhya Pradesh, Andhra Pradesh and Tamil Nadu states. The CALIPSO derived vertical feature mask image suggested vertically extended aerosol layer $(\sim 3 \mathrm{Km})$ over central Indian region on 25 October 20007 

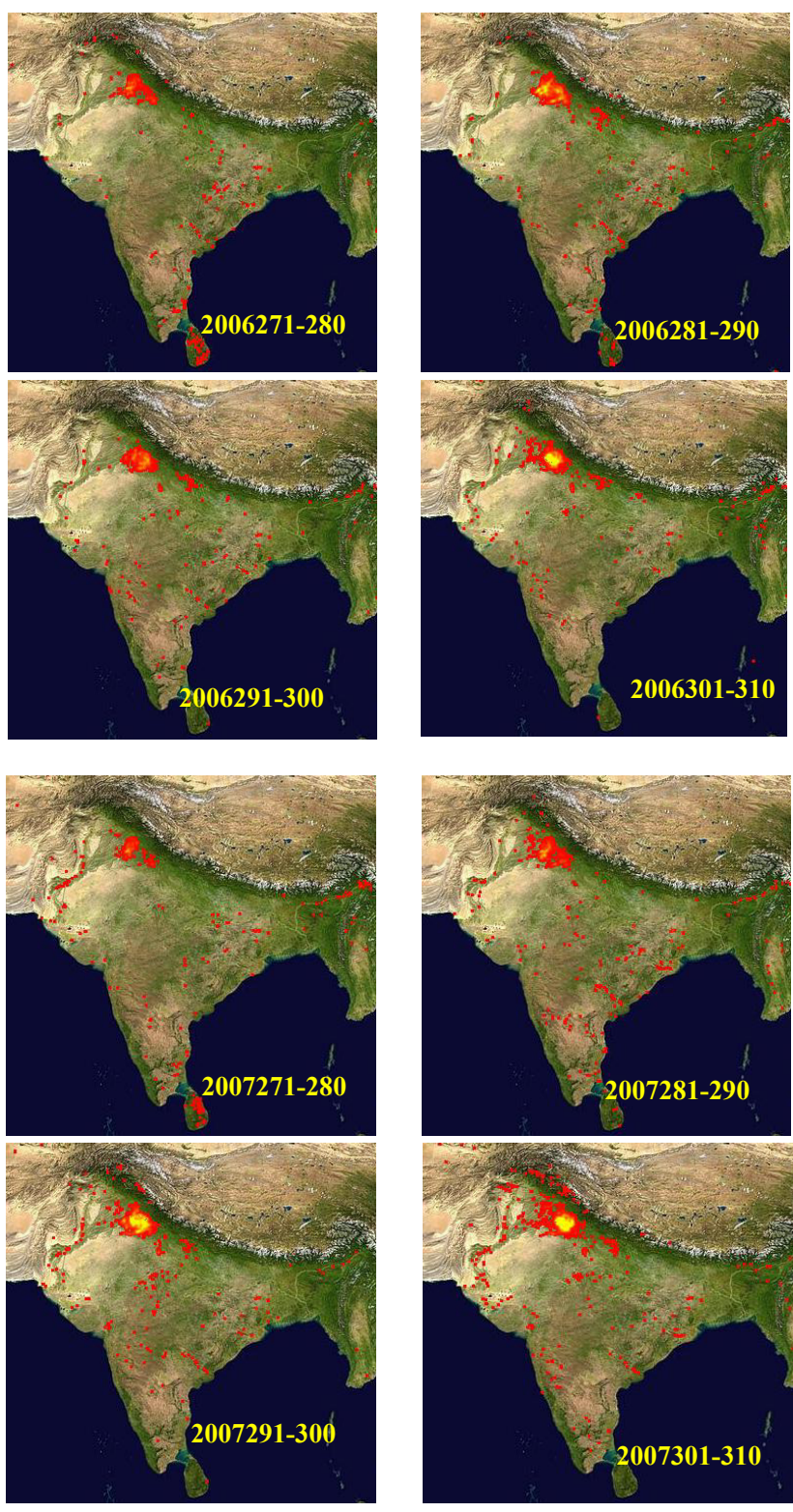

Fig. 13. MODIS active fires composite during October 2006 and 2007 showing increased occurrence of fires during October 2007.

associated with agriculture crop residue burning activities over the region. Figure 13 shows the MODIS active fire locations composite over Indian subcontinent during October 2006 and 2007. Higher incidence of fires occurred over the IGP region during 2007, mainly in the Punjab and Haryana state followed by Utter Pradesh, Madhya Pradesh and Maharashtra (Fig. 13). These fire practices are mainly attributed to agricultural crop residue burning associated with rice-wheat crop rotation system over the IGP region (Badarinath et al., 2006).
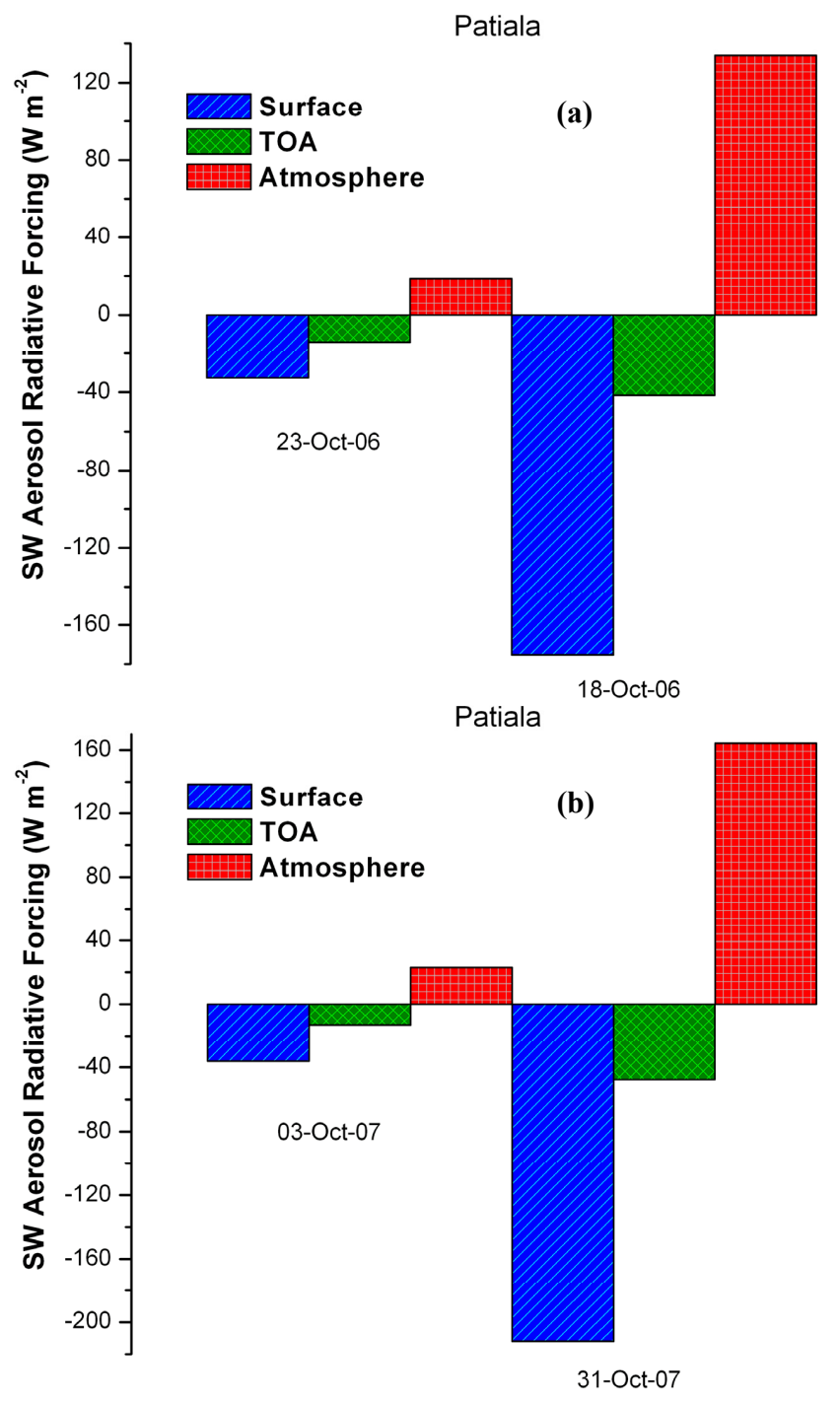

Fig. 14. Aerosol shortwave (SW) radiative forcing estimated using SBDART model over Patiala city during (a) 18 (turbid day) and 23 (clear day) October 2006 and (b) 3 (clear day) and 31 (turbid day) October 2007.

\subsection{Aerosol radiative forcing}

The knowledge of aerosol loading is important as it can influence the weather patterns by perturbing the radiation budget over any region. The radiative forcing from biomass burning aerosols has been a subject of scientific research at regional and global scale. In the present study, we have used aerosol optical depth (AOD) data measured using MWR (Gogoi et al., 2008) as input to Optical Properties of Aerosol and Clouds (OPAC) model to calculate single scattering albedo $(\omega)$ and asymmetry factor values. The radiative transfer calculations were made using the Santa Barbara Discrete Ordinate Radiative Transfer (SBDART) (Ricchiazzi et al., 1998) algorithm. This hybrid approach has been used 
successfully to estimate the aerosol radiative forcing (Badarinath et al., 2009). The calculations were performed separately with and without aerosols for shortwave spectrum $(0.2-4.0 \mu \mathrm{m})$ and the clear sky radiative forcing was determined over the study site. Figure 14 shows shortwave (SW) direct radiative forcing at the surface (SRF), TOA and atmosphere over study site during (a) 18 (turbid day) and 23 (clear day) October 2006 and (b) 3 (clear day) and 31 (turbid day) October 2007. Considerable reduction in surface reaching shortwave radiation i.e. $\sim-175.4 \mathrm{~W} \mathrm{~m}^{-2}$ during 18 October 2006 and $\sim-212.1 \mathrm{~W} \mathrm{~m}^{-2}$ during 31 October 2007 were observed during biomass burning period at the study site. The SW radiative forcing at TOA was $\sim-41.48 \mathrm{~W} \mathrm{~m}^{-2}$ and $\sim-47.67 \mathrm{~W} \mathrm{~m}^{-2}$ over the region during 18 October 2006 and 31 October 2007, respectively. The reduction in surface SW radiation resulted in large atmospheric SW forcing of about $\sim 134 \mathrm{~W} \mathrm{~m}^{-2}$ and $\sim 164.4 \mathrm{~W} \mathrm{~m}^{-2}$ during 18 October 2006 and 31 October 2007, respectively. The increased absorption of shortwave radiation results in atmospheric heating that can have possible impact on climate over the region. Earlier studies by Tripathi et al. (2005) highlighted a decrease in the shortwave radiation reaching the surface $\sim 62 \pm 23 \mathrm{~W} \mathrm{~m}^{-2}$ and the top of the atmosphere (TOA) reflected radiation by $\sim 9 \pm 3 \mathrm{~W} \mathrm{~m}^{-2}$ over Kanpur located in the IGP region, India. Badarinath and Latha (2006) suggested aerosol forcing of $-33 \mathrm{Wm}^{2}$ and $+9 \mathrm{~W} \mathrm{~m}^{-2}$ at the surface and at the top of the atmosphere respectively over urban region of Hyderabad. Bellouin et al. (2005) estimated radiative forcing using state-of-the-art satellite based measurements of aerosols, surface wind speed and highlighted a clear sky global direct radiative forcing of $-1.9 \pm 0.3 \mathrm{~W} \mathrm{~m}^{-2}$ at TOA. Wang et al. (2007) estimated regional radiative impact of biomass burning aerosols in the Asia during the experimental period of Transport and Chemical Evolution over the Pacific (TRACE-P) and suggested monthly mean clearsky direct shortwave radiative forcing ranging from -1.9 to $0.4 \mathrm{~W} \mathrm{~m}^{-2}$ at TOA and from -0.5 to $-12.0 \mathrm{~W} \mathrm{~m}^{-2}$ at surface. Recently Badarinath et al. (2009) observed radiative forcing in the range of $\sim-107.81 \mathrm{~W} \mathrm{~m}^{-2}$ at surface over urban region of Hyderabad due to enhanced aerosols loading associated with agriculture crop residue burning.

\section{Conclusions}

In the present study, impact of agriculture crop residue burning on aerosol properties during October 2006 and 2007 years over Punjab state in the IGP region of India were analyzed. Results of the study suggested that

- Higher values of $\mathrm{AOD}_{500}, \alpha$ and $\beta$ exhibited during crop residue burning period suggesting increased concentration of accumulation mode particle in the atmosphere with high turbidity conditions. The AOD values were $\sim 21 \%$ higher during October 2007 compared to October 2006 and were attributed to agriculture crop residue burning over the region.

- Satellite derived observations on AOD, aerosol index $(\mathrm{AI}), \mathrm{NO}_{2}$ and carbon monoxide $(\mathrm{CO})$ showed significant increase during October 2007 compared to October 2006 coinciding with ground observations of aerosol parameters.

- Model estimates on aerosol shortwave radiative forcing suggested increased atmospheric absorption of radiation during crop residue burning period over the region.

Acknowledgements. The authors thank the Director of NRSC \& Deputy. Director (RS\&GIS-AA), NRSC for necessary help at various stages and ISRO-GBP for funding support.

Topical Editor F. D'Andrea thanks D. Kaskaoutis and another anonymous referee for their help in evaluating this paper.

\section{References}

Andreae, M. O. and Merlet, P.: Emission of trace gases and aerosols from biomass burning, Global Biogeochemical Cycles, 15, 955966, 2001.

Andreae, M. O., Jones, C. J., and Cox, P. M.: Strong present-day aerosol cooling implies a hot future, Nature, 435, 1187-1190, 2005.

Ångström, A.: The parameters of atmospheric turbidity, Tellus, 16, 64-75, 1964.

Badarinath, K. V. S., Kharol, S. K., Kaskoutis, D. G., and Kambezidis, H. D.: Influence of atmospheric aerosols on solar spectral irradiance in an urban area, J. Atmos. Solar-Terr. Phys., 69, 589-599, 2007.

Badarinath, K. V. S., Kiran Chand, T. R., and Prasad, V. K.: Agriculture crop residue burning in the Indo-Gangetic plains - A study using IRS P6 AWiFS satellite, Current Sci., 91, 10851089, 2006.

Badarinath, K. V. S. and Latha, K. M.: Direct radiative forcing from black carbon aerosols over urban environment, Adv. Space Res., 37, 2183-2188, 2006.

Badarinath, K. V. S., Kharol, S. K., and Sharma, A. R.: Long-range transport of aerosols from agriculture crop residue burning in Indo-Gangetic Plains - A study using LIDAR, ground measurements and satellite data, J. Atmos. Solar-Terr. Phys., 71, 112120, 2009a.

Badarinath, K. V. S., Kharol, S. K., Krishna Prasad, V., Kaskaoutis, D. G., and Kambezidis, H. D.: Variation in aerosol properties over Hyderabad, India during intense cyclonic conditions, Int. J. Remote Sens., 29(15), 4575-4597, 2008.

Badarinath, K. V. S., Kharol, S. K., Sharma, A. R., and Krishna Prasad, V.: Analysis of aerosol and carbon monoxide characteristics over Arabian Sea during crop residue burning period in the Indo-Gangetic Plains using multi-satellite remote sensing datasets, J. Atmos. Solar-Terr. Phys., 71, 1267-1276, 2009 b.

Badarinath, K. V. S., Kharol, S. K., Sharma, A. R., Ramaswamy, V., Kaskaoutis, D. G., and Kambezidis, H. D.: Investigations of an intense aerosol loading during 2007 cyclone SIDR - A study using satellite data and ground measurements over Indian region, Atmos. Environ., 43, 3708-3716, 2009c. 
Bellouin, N., Boucher, O., Haywood, J., and Reddy, M. S.: Global estimate of aerosol direct radiative forcing from satellite measurements, Nature, 438, 1138-1141, doi:10.1038/nature04348, 2005.

Boersma, K. F., Bucsela, E., Brinksma, E., and Gleason, J. F.: NO2, in: OMI Algorithm Theoretical Basis Document, vol. IV, Trace Gas Algorithms, edited by: Chance, K., pp. 15-36, NASA Goddard Space Flight Cent., Greenbelt, Md., 2002.

Bucsela, E. J., Celarier, E. A., Wenig, M. O., Gleason, J. F., Veefkind, J. P., Booersma, K. F., and Brinksma, E. J.: Algorithm for NO2 vertical column retrieval from the Ozone Monitoring Instrument, IEEE Trans. Geosci. Remote Sens., 44(5), 1245-1258, 2006.

Cattani, E., Costa, M. J., Torricella, F., Levizzani, V., and Silva, A. M.: Influence of aerosol particles from biomass burning on cloud microphysical properties and radiative forcing, Atmos. Res., 82, 310-327, 2005.

Celarier, E., Brinksma, E., Gleason, J., Wenig, M., Veefkind, J., Cede, A., Herman, J., Ionov, D., Goutail, F., Pommereau, J.-P., Lambert, J.-C., van Roozendahl, M., Pinardi, G., Wittrock, F., Schonhardt, A., Richter, A., Ibrahim, O., Wagner, T., Bojkov, B., Mount, G., Bucsela, E., Swart, D., Volten, H., Kroon, M., and Levelt, P.: Validation Ozone Monitoring Instrument nitrogen dioxide columns, J. Geophys. Res., 113, D15S15, doi:10.1029/2007JD008908, 2008.

Curier, L., Veefkind, J. P., Braak, R., Torres, O., Veihelmann, B., and Leeuw, G. de,: Retrieval of aerosols optical properties from OMI radiances using a multi-wavelength algorithm: Application and validation to Western Europe, J. Geophys. Res. D, 2008, doi:10.1029/2007JD008738, 2008.

Das, S. K., Jayaraman, A., and Misra, A.: Fog-induced variations in aerosol optical and physical properties over the Indo-Gangetic Basin and impact to aerosol radiative forcing, Ann. Geophys., 26, 1345-1354, 2008,

http://www.ann-geophys.net/26/1345/2008/.

de Graaf, M. and Stammes, P.: SCIAMACHY Absorbing Aerosol Index - calibration issues and global results from 2002-2004, Atmos. Chem. Phys., 5, 2385-2394, 2005,

http://www.atmos-chem-phys.net/5/2385/2005/.

Deeter, M. N., Emmons, L. K., Francis, G. L., et al.: Evaluation of operational radiances for the Measurements of Pollution in the Troposphere (MOPITT) instrument CO thermal-band channels, J. Geophys. Res., 109(D3), D03308, doi:10.1029/2003JD003970, 2004.

Draxler, R. R. and Rolph, G. D.: HYSPLIT (Hybrid Single-Particle Lagrangian Integrated Trajectory) model, http://www.arl.noaa. gov/ready/hysplit4.html, NOAA Air Resour. Lab., Silver Spring, MD, 2003.

Edwards, D. P., Emmons, L. K., Hauglustaine, D. A., et al.: Observations of carbon monoxide and aerosols from the Terra satellite: Northern Hemisphere variability, J. Geophys. Res., 109, D24202, doi:10.1029/2004JD004727, 2004.

Giglio, L., Kendall, J. D., and Mack, R.: A multi-year active fire data set for the tropics derived from the TRMM VIRS, Int. J. Rem. Sens., 24, 4505-4525, 2003.

Gogoi, M. M., Bhuyan, P. K., and Krishna Moorthy, K.: Estimation of the effect of long-range transport on seasonal variation of aerosols over northeastern India, Ann. Geophys., 26, 1365-1377, 2008 , http://www.ann-geophys.net/26/1365/2008/.

Gustafsson, O., Krusa, M., Zencak, Z., Sheesley, R. J., Granat, L., Engstrom, E., Praveen, P. S., Rao, P. S. P., Leck, C., and Rodhe, H.: Brown Clouds over South Asia: Biomass or Fossil Fuel Combustion?, Science, 323, 495-498, 2009.

Guyon, P., Frank, G. P., Welling, M., Chand, D., Artaxo, P., Rizzo, L., Nishioka, G., Kolle, O., Fritsch, H., Silva Dias, M. A. F, Gatti, L. V., Cordova, A. M., and Andreae, M. O.: Airborne measurements of trace gas and aerosol particle emissions from biomass burning in Amazonia, Atmos. Chem. Phys., 5, 2989-3002, 2005, http://www.atmos-chem-phys.net/5/2989/2005/.

Habib, G., Venkataraman, C., Chiapello, I., Ramachadran, S., Boucher, O., and Reddy, M. S.: Seasonal and interannual variability in absorbing aerosols over India derived form TOMS: Relationship to regional meteorology and emissions, Atmos. Environ., 40, 1909-1921, 2006.

Kaskaoutis, D. G. and Kambezidis, H. D.: Investigation on the wavelength dependence of the aerosol optical depth in the Athens area, Q. J. Roy. Meteorol. Soc., 132, 2217-2234, 2006.

Kaskaoutis, D. G., Kambezidis, H. D., Adamopoulos, A. D., and Kassomenos, P. A.: Comparison between experimental data and modeling estimates of atmospheric optical depth over Athens, Greece, J. Atmos. Solar Terr. Phys., 68, 1167-1178, 2006.

Kaskaoutis, D. G., Kambezidis, H. D., Hatzianastassiou, N., Kosmopoulos, P. G., and Badarinath, K. V. S.: Aerosol climatology: dependence of the Ångström exponent on wavelength over four AERONET sites, Atmos. Chem. Phys. Discuss., 7, 7347-7397, 2007 , http://www.atmos-chem-phys-discuss.net/7/7347/2007/.

Kaskaoutis, D. G. and Kambezidis, H. D.: Comparison of the Ångström parameters retrieval in different spectral ranges with the use of different techniques, Meteorol. Atmos. Phys., 99, 233246, 2008.

Kaskaoutis, D. G., Kambezidis, H. D., Nastos, P. T., and Kosmopoulos, P. G.: Study on an intense dust storm over Greece, Atmos. Environ., 42, 6884-6896, 2008.

Kaufman, Y. J. and Tanre, D.: Algorithm For Remote Sensing of Tropospheric Aerosol from MODIS, Algorithm Theoretical Basis Document, ATBD-MOD-02, NASA Goddard Space Flight Center, 85, 1998.

Kharol, S. K. and Badarinath, K. V. S.: Impact of biomass burning on aerosol properties over tropical urban region of Hyderabad, India, Geophys. Res. Lett., 33, L20801, doi:10.1029/2006GL026759, 2006.

Levy, R. C., Remer, L. A., and Dubovik, O.: Global aerosol optical properties and application to Moderate Resolution Imaging Spectroradiometer aerosol retrieval over land, J. Geophys. Res., 112, D13210, doi:10.1029/2006JD007815, 2007.

Liu, J., Drummond, J. R., Li, Q., Gille, J. C., and Ziskin, D. C.: Satellite mapping of $\mathrm{CO}$ emission from forest fires in Northwest America using MOPITT measurements, Remote Sens. Environ., 95(4), 502-516, 2005.

Menon, S., Hansen, J. E., Nazarenko, L., and Luo, Y.: Climate effects of black carbon aerosols in China and India, Science, 297, 2250-2253, doi:10.1126/science.1075159, 2002.

Mittal, S. K., Singh, N., Agarwal, R., Awasthi, A., and Gupta, P. K.: Ambient air quality during wheat and rice crop stubble burning episodes in Patiala, Atmos. Environ., 43(2), 238-244, 2009.

Moorthy, K. K., Niranjan, K., Narasimhamurthy, B., Agashe, V. V., 
and Murthy, B. V. K.: Aerosol climatology over India: ISRO GBP MWR network and database, ISRO GBP SR-03-99, Indian Space Res. Organ., Bangalore, 1999.

Pandey, J. S., Kumar, R., and Devotta, S.: Health risks of $\mathrm{NO}_{2}$, $\mathrm{SPM}$ and $\mathrm{SO}_{2}$ in Delhi, Atmos. Environ., 39(36), 6868-6874, 2005.

Pedros, R., Martinez-Lozano, J. A., Utrillas, M. P., Gomez-Amo, J. L., and Tena, F.: Column-integrated aerosol, optical properties from ground-based spectroradiometer measurementsat Barrax (Spain) during the Digital Airborne Imaging Spectrometer Experiment (DAISEX) campaigns, J. Geophys. Res., 108(D18), 4571, doi:10.1029/2002JD003331, 2003.

Pillai, P. S. and Krishna Moorthy, K.: Size distribution of nearsurface aerosols and its relation to the columnar aerosol optical depths, Ann. Geophys., 22, 3347-3351, 2004, http://www.ann-geophys.net/22/3347/2004/.

Platt, U.: Differential optical absorption spectroscopy (DOAS), in: Air Monitoring by Spectroscopic Techniques, edited by: Sigrist, M., 27-84, John Wiley, Hoboken, NJ, 1994.

Powell, K. A., Hostetler, C. A., Vaughan, M. A., Lee, K., Trepte, C. R., Rogers, R. R., Winker, D. M., Liu, Z., Kuehn, R. E., Hunt, W. H., and Young, S. A.: CALIPSO Lidar Calibration Algorithms: Part I - Nighttime 532-nm Parallel Channel and 532-nm Perpendicular Channel, J. Atmos. Oceanic Technol., 26(10), 20152033, 2009.

Ramanathan, V., Ramana, M. V., Roberts, G., Kim, D., Corriganm, C., Chung, C., and Winker, D.: Warming trends in Asia amplified by brown cloud solar absorption, Nature, 448, 575-578, 2007.

Remer, L. A., Kaufman, Y. J., Tanre, D., Mattoo, S., Chu, D. A., Martins, J. V., Li, R.-R., Ichoku, C., Levy, R. C., Kleidman, R. G., Eck, T. F., Vermote, E., and Holben, B. N.: The MODIS Aerosol Algorithm, Products and Validation, J. Atmos. Sci., Special Issue, 62, 947-973, 2005.

Ricchiazzi, P., Yang, S., Gautier, C., and Sowle, D.: SBDART, a research and teaching tool for plane-parallel radiative transfer in the Earth's atmosphere, B. Am. Meteorol. Soc., 79, 2101-2114, 1998.

Rothery. D. A., Coppola, D., and Saunders, C.: Analysis of volcanic activity patterns using MODIS thermal alerts, Bulletin of Volcanology, 67(6), 539-556, 2005.
Schuster, G. L., Dubovik, O., and Holben, B. N.: Ångström exponent and bimodal aerosol size distributions, J. Geophys. Res., 111, D07207, doi:101029/2005JD006328, 2006.

Stone, E. A., Lough, G. C., Schauer, J. J., Praveen, P. S., Corrigan, C. E., and Ramanathan, V.: Understanding the origin of black carbon in the atmospheric brown cloud over the Indian Ocean, J. Geophys. Res., 112, D22S23, doi:10.1029/2006JD008118, 2007.

Tripathi, S. N., Dey, Sagnik, Chandel, A., Srivastava, S., Singh, Ramesh P., and Holben, B. N.: Comparison of MODIS and AERONET derived aerosol optical depth over the Ganga Basin, India, Ann. Geophys., 23, 1093-1101, 2005, http://www.ann-geophys.net/23/1093/2005/.

Tripathi, S. N., Dey, S., Tare, V., and Satheesh, S. K.: Aerosol black carbon radiative forcing at an industrial city in northern India, Geophys. Res. Lett., 32, L08802, doi:10.1029/2005GL022515, 2005.

van der Werf, G. R., Randerson, J. T., Giglio, L., Collatz, G. J., Kasibhatla, P. S., and Arellano Jr., A. F.: Interannual variability in global biomass burning emissions from 1997 to 2004, Atmos. Chem. Phys., 6, 3423-3441, 2006, http://www.atmos-chem-phys.net/6/3423/2006/.

Vinoj, V., Satheesh, S. K., Suresh Babu, S., and Krishna Moorthy, K.: Large aerosol optical depths observed at an urban location in southern India associated with rain-deficit summer monsoon season, Ann. Geophys., 22, 3073-3077, 2004, http://www.ann-geophys.net/22/3073/2004/.

Wang, J. and Christopher, S. A.: Intercomparison between satellitederived aerosol optical thickness and PM2.5 mass: Implications for air quality studies, Geophys. Res. Lett., 30(21), 2095, doi:10.1029/2003GL018174, 2003.

Wang, S. H., Lin, N. H., Chou, M. D., and Woo, J. H.: Estimate of radiative forcing and regional feedback of Asian biomass burning aerosols during the period of TRACE-P, J. Geophys. Res., 112, D10222, doi:10.1029/2006JD007564, 2007. 